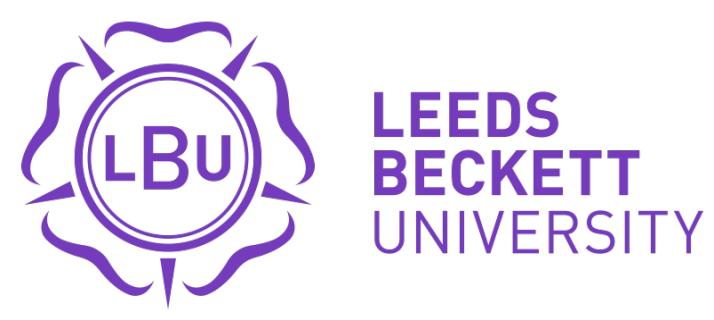

Citation:

Hylton, K and Lawrence, S (2016) 'For Your Ears Only!' Donald Sterling and Backstage Racism in Sport. Ethnic and Racial Studies, 39 (15). pp. 2740-2757. ISSN 1466-4356 DOI: https://doi.org/10.1080/01419870.2016.1177193

Link to Leeds Beckett Repository record:

https://eprints.leedsbeckett.ac.uk/id/eprint/2297/

Document Version:

Article (Updated Version)

The aim of the Leeds Beckett Repository is to provide open access to our research, as required by funder policies and permitted by publishers and copyright law.

The Leeds Beckett repository holds a wide range of publications, each of which has been checked for copyright and the relevant embargo period has been applied by the Research Services team.

We operate on a standard take-down policy. If you are the author or publisher of an output and you would like it removed from the repository, please contact us and we will investigate on a case-by-case basis.

Each thesis in the repository has been cleared where necessary by the author for third party copyright. If you would like a thesis to be removed from the repository or believe there is an issue with copyright, please contact us on openaccess@leedsbeckett.ac.uk and we will investigate on a case-by-case basis. 


\title{
'For Your Ears Only!' Donald Sterling and Backstage Racism in Sport
}

\section{Kevin Hylton ${ }^{1}$ and Stefan Lawrence ${ }^{2}$}

Received 27/10/2015; Accepted 11/01/2016

\begin{abstract}
The purpose of this paper is to elucidate how racism manifests 'behind closed doors' in the backstage private domain. We do this with reference to recent high-profile controversies in the US and UK. In particular, we use the concepts of frontstage (public) and backstage (private) racism to unpack the extraordinary case in point of the ex-National Basketball Association (NBA) franchise owner Donald Sterling. The paper concludes that though it is important for frontstage racism to be disrupted, activist scholars must be mindful of the lesser-known, and lesser-researched, clandestine backstage racism that, we argue, galvanises more public manifestations. The Donald Sterling case is an example of how backstage racism functions and, potentially, how it can be resisted.
\end{abstract}

Racism; Backstage; Frontstage; Sport; Donald Sterling; Whiteness

${ }^{1}$ Carnegie Faculty, Leeds Beckett University, Leeds, UK (corresponding author)

2 Physical Education and Sport Studies, Newman University, Birmingham, UK 


\section{Introduction}

Sport has played host to a number of high-profile racially motivated incidents in recent years. Though not always the case, the leading protagonists, who draw our attention more readily, tend to be high profile White males with power, wealth and influence. Players, managers, spectators, and senior officials have been joined by media figures that fall foul of public standards by sharing racist or sexist sentiments. Whereas an increasing number in sport attempt to disrupt overt expressions of racism and/or racist intent there remains a less well understood and less accessible part of sport reserved for those more likely to share morally reprehensible views.

The purpose of this paper is to elucidate how racism manifests 'behind closed doors' in the backstage private domain. We do this with reference to recent highprofile controversies in the US and UK. In particular, we use the concepts of frontstage (public) and backstage (private) racism to unpack the extraordinary case of the ex-National Basketball Association (NBA) franchise owner Donald Sterling (Hughey 2011, Picca and Feagin 2007). One of the most high profile stakeholders in U.S. sport, and property mogul, Sterling found himself defending the indefensible because his backstage racist comments were not meant for public consumption. We focus on applying these theoretical ideas rather than purely to raise awareness of theory, but with a view to disrupt this lesser understood form of racism (Rains 2000). The paper concludes that though it is important for frontstage racism to be disrupted, activist scholars must be mindful of the lesser-known, and lesserresearched, clandestine backstage racism that, we argue, galvanises more public 
manifestations. As a result of new patterns of racism emerging the potential for studies on backstage racism to explain ambiguous racial inequalities and discrimination in sport become more apparent. The Donald Sterling case is an example of how backstage racism functions and, potentially, how it can be resisted.

In order to demonstrate the dangers of backstage racism we apply Feagin's notion of frontstage and backstage 'race' talk to a sporting context, which has emerged from his work on the White racial frame (Picca and Feagin 2007, Feagin 2010, Hughey 2011). Feagin describes the White racial frame as a worldview that helps structure and make sense of society based upon racial stereotypes, narratives and interpretations, imagery, racialised emotions and inclinations toward discrimination (Feagin 2010,11). The frame is also a device to share cultural information in the form of discourses that reinforce subordination and oppression in society. Significantly, practice of the frame also hints at the intersections of people's material, social and mental lives (Feagin 2010, 13).

In comparison with the under-researched work on whiteness and critical race theorising in sport and leisure the use of frontstage and backstage talk has received even less attention. Hylton (2015) argues that sport and leisure studies, and PE are myopic, constrained in their overall inclusion of 'race'. He goes on to suggest that the adherence to dominant ideas and epistemologies leads to the reproduction of values and knowledge formers in disciplines. Hence much of the research conducted in the social sciences, whether through available resources or 
individual choice, tend to follow established patterns, which shy away from questions that challenge this hegemony. Our concern with the insidious nature of the 'backstage' converges with the absence of these issues in sport. Reasons for this likely includes the ethical sensitivity required of any exploration of private spaces, the dominance of more popular topics in sport theorising, combined with challenging grievous matters of 'race', racism and whiteness.

\section{Racism in sport}

Muller et al (2007) note that in relation to 'race' and racism sport sociologists have focused on four particular areas of concern which we use here to frame a review of the literature. The first area they identify emerges from a number of studies of racism in sport which focus on the vernacular (Back, Crabbe, and Solomos 1999, 2001). Racist chanting at high profile sports matches and racial slurs uttered during altercations between individuals, at both grassroots and elite levels of sport, are two such examples (Cleland and Cashmore 2014). This kind of research, its exploration of language and the racialised meanings attached to the spoken word, has identified the decreasing, but nevertheless socially significant, occurrences of overt forms of colour-based racism in public spaces. Though there is resilience to this form of racism in sport much of it is concerned with dominant male oriented sports.

The second significant area identifiable in the literature focuses on occupational issues. In contrast to those studies concerned primarily with linguistics, these studies have sought to explain phenomena such as stacking 
(Maguire 1991), the dearth of Black leaders in sport (Cashmore and Cleland 2011), the underrepresentation of South Asian people in professional sport (Burdsey 2004, Fleming et al. 2005) and arguments for and against equal opportunities which includes the implementation of the 'Rooney Rule' (Duru 2011). Centralising the sporting workplace, and marking it as a place laden with social and cultural barriers, has brought attention to the outcomes of policy processes, recruitment procedures and governance, as opposed to individual actions. These concerns that focus a critical lens on the everyday complexities of occupational issues augment any preoccupation with the relatively simple manifestations of racism in the vernacular.

Such racialised outcomes in the workplace are made possible to critique because of our third area of concern: the institutional. Studies that have focused on institutional forms of racism in sport have enabled sport sociologists to: (1) consider the social relations that cause racial formations and the contributions of whiteness processes and pre-existing racial hierarchies (Hylton and Lawrence 2014); and (2) illustrate that current sporting structures often fail to comprehend racism beyond the vernacular and thus are ill-equipped to address sufficiently the complexities of racism(s). They have done this by emphasising how, contrary to their White counterparts, a lack of provision, access, capital (social, cultural, financial and educational) and role models are amongst a number of commonly overlooked racialised factors that obstruct or disrupt participation in sporting spheres for minoritised ethnic individuals and communities (Ratna, Lawrence, and Partington 2015). These studies assert that off-field social rituals, the historical 
legacy of racial inequalities, failures in practice and policy and racialised intolerance converge to create conditions, across various sports, whereby White, able-bodied, middle-class, heterosexual men are disproportionally advantaged to obtain and maintain status as players, coaches and administrators.

The fourth area that we wish to examine is the culture industry. It seeks to establish media's role in perpetuating and/or challenging racialisation and racism in sport (van Sterkenburg, Knoppers, and Leeuw 2010). Numerous scholars of sport media contend that references to Black athletes as erratic but strong, physical and quick (Hughey and Goss 2015), and to White athletes as intelligent, diligent and hardworking (Lawrence 2014b), dominate commentaries and reports. In turn, concerned primarily with media strategies of representation and audience reception, this body of literature observes that sport media commentators and producers often operate with an implicit bio-racist logic but encounter very little censure because of the coded ways in which racialised messages are delivered. Understanding better how 'positive' media representation has astutely negative social implications for minoritised athletes and communities, more broadly, is a major contribution of such studies to the sociology of 'race' and racism in sport (Carrington 2013).

This scholarly literature has arguably contributed to the emergence and success of a number of anti-racist campaigns. Positive outcomes have resulted from liberally minded anti-racist movements, politicians and scholars and, as such, overt 
verbal racism - in and away from - sporting arenas has become less crude than in previous years. The many calls for respect and antiracism plastered across billboards at major sporting events are testimony to this. However, while arrests for racist chanting at sport matches in the UK, during the early twenty-first century may be declining (Home Office 2014), a scholarly focus on occupational, institutional and cultural processes has served to confound the notion that racism has simply disappeared because it is less overtly egregious than two or three decades ago.

A reading of the literature on racism in sport encourages us to think about and make visible a plurality of racisms that we argue is a worthy political and intellectual exercise. Despite this it also reveals how sociological analyses of sport have neglected empirical and theoretical explorations of more surreptitious backstage racisms for more common manifestations. Limitations in balancing explorations of more subtle and covert forms of racism in frontstage arenas with investigations of racisms in the backstage have meant our knowledge concerning the latter requires further attention.

Authors' experiences of being...front and backstage

The two authors of this paper have very different biographies and therefore divergent experiences of frontstage and backstage 'race' talk. Hylton has a Black colonial heritage born of parents arriving in 1950s London not to find 'streets paved with gold'. In fact they were 'welcomed' with signs in guesthouse and hotel windows, and other public spaces, warning 'Blacks need not apply'. A child of the 
60s and 70s, 'race' has always been an imposition, and central, to his identity, though the nature of the racism experienced by his parents has metamorphosised into more sophisticated versions today. Hence, examinations of racialised dynamics and 'race' are necessarily an ontological starting point for research especially in what is often described as the meritocracy of sport.

Lawrence was also born in England, during the 1980s, though has a mixed White-European heritage (see also Lawrence 2014a). At variance with Hylton's recollections, Lawrence cannot recall feeling the matter of 'race' affected his childhood: he cannot remember being told that his achievements as a child were a result of anything but hard work; and never was he made to feel that he was 'minority ethnic', despite his father's family having migrated from Italy/ Sicily in the early 1950s. Therefore, although he was aware of subtle ethnic differences between himself and his peers, he was never marked as having a racial identity or as being significantly (read: racially) different from the majority of his peers, teachers or sport coaches.

Being read corporeally, and thus racialised, as White had granted him access to a number of privileges that were and are often reserved for those admitted to the 'private club of whiteness' (Jensen 2005). A positive association (determined largely somatically and thus, in some cases, unknowingly) that grants members, not only privilege but also, access to a number of restricted, private spaces, often reserved for White people or particularly 'deserving' Others. One such arena is in the 
backstage, a private space wherein a seemingly forgotten form of Whiteness and racism festers. Racisms are not only constructed and rehearsed but they are defended, perpetuated and resisted. Backstage is not one 'thing' but a variegated context that includes the 'level playing field' of sport, ranging from sophisticated to down-to-earth settings where racisms continue to operate everyday. And so, despite his political and ideological opposition Lawrence has been routinely 'witness to whiteness' in the backstage (see Fine 2004).

Thinking frontstage and backstage

One of the most important achievements of liberal anti-racist policies has been their ushering in of an epoch defining cultural imperative that is largely intolerant of overt and bigoted racisms in public spaces. For instance, relatively few people, today, as was common in the 1970 s and 1980 s, would consider throwing a banana at a Black football player as acceptable behaviour. This was made clear in the way Danny Alves, the Barcelona and Brasil defender was publicly supported across all media platforms after a banana was thrown at him while playing against Villarreal CF. In a short space of time the perpetrator was found and punished, the club was fined, Twitter and other social media were alive with antiracist sentiment. Today, if this type of abhorrent overtly racist behaviour is witnessed in a public forum then perpetrators are often publically or legally castigated.

This is certainly not to say however that racisms no longer operate in public spaces. Absolutely they do. However, as Solomos and Back $(1996,27)$ note, 
"[c]ontemporary racisms have evolved and adapted in new circumstances". In other terms, while 'old', bigoted, colour racisms, rooted in the notion of biological differences between 'races', and/or a severe dislike of a person because of their 'race', are demonised by dominant liberal political and cultural agendas, frontstage racisms have become increasingly more subtle, cooperative and less obvious.

While much current research in sport has sought to understand the complexities of 'new' racisms, especially those that operate clandestinely in frontstage arenas, focusing overly on the ways in which racial prejudices operate in these public spaces can unwittingly lend support to a post-race dogma; one that argues racism today is heinous, ergo a thing of the past. It suggests that racism is not tolerated and is merely the domain of socially dysfunctional individuals/entities. In sum, focusing solely on covert, systemic, frontstage racisms as the a priori object of analysis marginalises outward displays of bigotry in the backstage. In turn, Picca and Feagin $(2007,22)$, for instance, warn against reaching such conclusions "about a 'new racism' or a 'colorblind racism' that is greatly different from the past... The majority of White people still participate in openly racist performances in the backstage arena". This is certainly not to argue that 'new racisms', or enquiries into the frontstage, are theoretically or politically insignificant; however, it is to suggest that 'old' colour-based and individual racisms should not be treated as inconsequential or out-dated either.

The public condemnations of racism, especially in the arena of sport, is powerful and persuasive enough to force those with less palatable views to offer a 
more diluted, rationalised version of what they might think of others. However, it is in these moments, in perceived private spaces, when such actors are less guarded and backstage 'race' talk is promulgated. In the way that Goffman (1990 [1959]) argues individuals present a version of themselves through guiding and controlling an impression, a number of scholars have suggested that White people often discuss matters of 'race', with one another, in private spaces, differently than they would usually in the frontstage. This unwritten code of backstage 'race' talk then, wherein White people feel free to speak openly and sometimes crudely about 'race' and the racialised Other (Bonilla-Silva, 2002; Feagin, 2010; Hughey, 2011), not only challenges those who claim progress is being made regarding attitudes towards racial equality but it is significantly under-researched.

\section{Racialised controversies in sport}

Over the last four decades racism in global sport has become more newsworthy as the 24-hour news-cycle gains pace across its many platforms. Further, the complex and systemic recurrence of racism is typified by recent controversies at Tottenham Hotspur FC (Spurs). In the 1980s football fans were fined for using the term Yid to denigrate Spurs supporters. Spurs have a strong connection with the Jewish community and maintain that today (RunnymedeTrust 1985, 6). Yet in 2014 Spurs fans were in turmoil over those who now use the term self-referentially as a badge of honour and those who still abhor the reference (Poulton and Durell 2014). Racism and xenophobia in sport is neither simple nor straightforward especially where in this case major stakeholders disagree on whether an act should be 
construed as such. For example, the Conservative Prime Minister David Cameron argues that it is fine to use the term while the English Football Association threaten to levy fines and bans (Johnson 2013, TelegraphSport 2013).

The nature of these racialised events and acts are a study in themselves, as sport acts as a microcosm of racism in society. The racialised events and racist acts that we experience in the media, and in some cases directly, cannot be rationalised as random, individual, or institutional because this is only a partial response to the embedded and more deleterious characteristics of racism's signatures in the everyday (Leonardo 2009, Delgado and Stenfancic 2012, Puwar 2004). Racism has a chameleon like tendency in its generational manifestations. Some have described the shift from biological and physiognomic based racisms to a 'new racism' that implies rather than names racial superiority (Mason 2013, Bonilla-Silva 2010). Yet we intend to demonstrate that in many cases the 'old', colour-based, nasty racism is omnipresent, though experienced in new ways.

Partial responsibility for sport's inability to counter the racism in its midst is its historically White and largely unaffected leadership, and the hegemony of whiteness which remains under-critiqued. The prevalence of whiteness at the highest levels of sport governance has led many to criticise the racialised hierarchies that have formed to the exclusion of Black and minoritised ethnic bodies. Bradbury, van Sterkenburg, and Mignon (2015), Cleland and Cashmore (2014), Burdsey (2011), Ratna (2011) are all concerned with sport's penchant with 
colourblindness and 'level playing field' ideologies affecting its relative inability to critically engage processes of whiteness. Consequently this has led to asymmetrical racialised power relations, raced and gendered stereotypes and cultures.

The ability for those in power to resist change, ignore institutional racism, and lack reflexivity, is a consistent theme in sport whether the issues of negative racialised relations are concentrated on the field, terraces, office or boardroom (Long and Spracklen 2011). Such racialised acts and events do not occur in a vacuum and neither do their underpinnings and shared meanings (Hughey 2011). It can be argued that private backstage racist discussions are routine in everyday contexts yet their forms and content remain at the level of anecdote without research or backstage 'slippages' like those of Donald Sterling and others, to which we now turn.

Sterling and Co. backstage Recently, Donald Sterling (former owner of the LA Clippers), Jeremy Clarkson (exBBC Top Gear presenter), Richard Scudamore (Chief Executive of the English Premier League), and Malky Mackay (ex-Cardiff City FC manager) have found themselves defending unsavory comments made during backstage exchanges while holding posts in the upper echelons of sport and the media. Apologists for these men took quickly to radio, television and social media to support the accused, arguing simply: the overtly racist, sexist, homophobic and anti-Semitic comments, made by each man, happened in private and were not intended for public consumption. For 
some, such as rock star, Gene Simmons - who argues that everyone makes jokes that are off colour - Sterling 'was ambushed'. Similarly, television presenter Bill Maher defended Sterling using the $4^{\text {th }}$ amendment right to privacy as his standpoint. In the UK Michael Gove, Conservative MP defended Clarkson, and the League Managers' Association defended MacKay, they concurred that the public debate must go no further. Supposedly, there is no need for any further inquiry or analysis. The backstage context of these utterances ensures immunity and renders them inconsequential.

By the logic of these arguments it is unimportant that Sterling is troubled by his partner "associating with Black people", that Clarkson saw fit to subject his coworkers to the ' $\mathrm{N}$ ' word, that Scudamore, self-proclaimed activist in the "whole equality agenda", thought it acceptable to ridicule "female irrationality" and crudely objectify women, while football manager Mackay's string of racist, sexist and antiSemitic texts typified the delusional privacy of electronic communications. It would seem that if there is any debate to be had it is about the sanctity of all-White-male private spaces. But it is hardly surprising that highly influential figures have moved quickly to defend Sterling, Clarkson, MacKay and Scudamore's right to privacy if these four men are representative of how powerful, wealthy men talk to one another.

As with all popular scandals of this nature, whereby well-known figures are exposed as mere mortals, there is an obligatory PR offensive, concerned with 
damage limitation, spearheaded by an official apology. For instance, Scudamore's apology read:

"[The emails] were received and sent from my private and confidential email, which a temporary employee who was with the organisation for only a matter of weeks should not have accessed and was under no instruction to do so" (Lucas 2014) [Emphasis added]

Sterling and Clarkson, too, made similar pleas asking the public to understand that their utterances were never meant to be heard outside of a private setting. Significantly, Scudamore's response, in particular, reads as much as a defence as an apology. Clearly, he conveys in part that it is he who has been wronged in the wake of his private thoughts coming to light. His explanation asks the public to sympathise; he is a victim in this affair given his private space had been breached by a third-party. Indeed, while this may be so, a willingness to trivialise the significance of these recent revelations should be met with suspicion and opprobrium where there is little remorse. For instance, the League Managers' Association (LMA) statement in defence of Malky MacKay (BBC 2014) stated that it did:

Not condone any potential breach of equal opportunities laws...but that...out of over 10,000 text messages and 70,000 documents produced over a long period of time it may not 
be a complete surprise that some inappropriate comments

can sometimes be made by employees. [Emphasis added]

Though the LMA had to have the flaws in their press release pointed out to them, it becomes clear that the hegemony of a White racial frame is embedded in sport insofar as its stakeholders are willing to deny racism and unwilling to concede racism, sexism and/or homophobia are anything more than topics of "friendly text message banter". Its malevolence, therefore, cannot be underestimated and neither should it be ignored in theory or practice because to do so would be to underplay the place of the backstage in legitimising the White racial frame as an appropriate worldview.

When ITV football pundit and veteran manager, Ron Atkinson, attacked Marcel Desailly with a racist volley - describing the Black French footballer as "what is known in some schools as a fucking lazy, thick $\mathrm{n}^{* * * * * "}$ - he became an example of what happens when the 'backstage' enters the 'frontstage'. Atkinson unleashed such vitriol believing he was off air but unfortunately for him his words had been broadcast to audiences outside of the UK. Atkinson, after being relieved of his commentary duties by ITV later apologised for what he had said (although it is telling in that 'private' moment he was not pressed to apologise to his White male co-commentator). In recent years the media has reeled from many other such examples in football, not restricted to 'race'. For example ex-Sky Sport pundit/commentators Richard Keys and Andy Gray have been caught repeatedly 
sharing sexist comments about female officials and acting in misogynistic ways while in the company of female colleagues. In each recorded instance Keys and Gray were 'caught' in private (or safe) spaces expressing views that were designed to denigrate and embarrass women working in football. Rather than showing remorse, Gray in particular reported feeling 'stitched up' when his off-air comments about a female assistant referee being 'unlikely to know the offside rule' led to him being dismissed. Gray thus appeared more displeased with his behaviour being made public than he was about the harmful effects such comments and actions might have for the victims of his contempt. Enter, ex-LA Clippers basketball franchise owner, Donald Sterling.

\section{Backstage racism and frontstage defence}

Listening to Donald Sterling's conversation on YouTube with his self-described "mixed" partner, V. Stiviano, as he systematically outlined a racial credo that he and she must live by, it becomes clear that he does little to conceal the intent of his words (TMZ 2014). He is comfortable in this private, backstage space and is confident that he can rehearse arguments with Stiviano he would otherwise avoid in public. His ease in this seemingly normal space offers some insight into the types of 'safe' spaces Sterling inhabits. As the owner of a team heavily occupied by African American staff he is clearly prepared to publically engage and function in a way that facilitates cooperation and productive social relationships. Yet, in the backstage he reveals what seems to be a more racially closed and cynical identity. Doing what Love and Hughey (2015) state is a pattern emerging in sport of a shifting of overt 
racism from a public 'political correctness' to one of relative safety in private. In both front and backstage Sterling is fully functioning and conscious of the epistemologies he draws upon. In both cases he is a creature of the environments he inhabits. Mills $(1997,42)$ explains this when he argues that,

You are what you are in part because you originate from a certain kind of space, and that space has those properties in part because it is inhabited by creatures like yourself.

Until this conversation Stiviano was someone that Sterling felt met the criteria of a creature like himself. His argument, which revolves around his dislike of Stiviano's public association with Black sports people and her apathy toward racialised hierarchies in sport is forceful and lucid. He seems to have internalised the media hyperbole of the danger of Black men revealed in the stereotype of basketball players as violent, and who yearn for embodied signifiers of a criminal lifestyle that includes rap music, tattoos, and 'urban wear' (Lorenz and Murray 2014). Part of his anxiety revolves around fear of the Black male body and its potential threat to Stiviano's femininity which forces him to reinscribe/re-mark and subjugate Black bodies while re-establishing White supremacy in his sport (Leonard 2004). As such, Sterling speaks to her as a confidant/mentor would their philosophies, about how he perceives the world to be and how best to navigate a "culture" he is unwilling to use his influence to change. 
Sterling: There's a culture. People feel certain things. Hispanics feel certain things towards blacks. Blacks feel certain things towards other groups. It's been that way historically, and it will always be that way.

Stiviano: But it's not that way in my heart and mind.

Sterling: But maybe you want to adjust to the world.

Stiviano: People call you and tell you that I have black people on my Instagram. And it bothers you?

Sterling: Yeah it bothers me a lot that you want to broadcast that you associate with black people. Do you have to?

In many ways Sterling's attempt to control images of Black people in his private world resonate with initiatives in basketball to control the images of Blackness, through dress codes, and even the hiring practices of its predominantly African American roster of players (Lorenz and Murray 2014). Sterling is not a lone voice in basketball's anti-Black narrative, though many of these narratives are subtle and require a critical reading. In some ways, hearing Sterling's views on his reluctance to being seen in public with Black people and yet seeing his economic reliance on a 75\% African American league a classic case of interest convergence is revealed, which partially explains Sterling's reticence to share his backstage opinions more widely.

Sterling has the authority and influence to make public how he feels about racial ideologies but in this case he chooses to accept such views without 
reservation. Not only does he accept these views, he privately endorses them as hardened and reasonable realities. These are statements that redraw racialised lines across a sport which some state is an example par excellence of integration (Agyemang and Singer 2014). Drawing on epistemologies of ignorance reserved for spaces and audiences whose communication recreates and repairs the hegemony of racial hierarchies Sterling proceeds to reiterate these views so long as they do not compromise his business interests. Sterling attempts to impart ideas and knowledge of the world that require what Sullivan and Tuana (2007: 1) suggest involves Stiviano 'unlearning' her own ideals to better enable her to benefit from Sterling's racially structured world. A society that Sterling continues to purport to be a known reality of natural racial division and preferences. His views, uttered in the safety of the backstage bare frightening resemblance, albeit in a twenty first century context, to those of a tolerant plantation owner:

Stiviano: Do you know that you have a whole team that's black that plays for you?

Sterling: ... I support them and give them food, and clothes, and cars, and houses. Who gives it to them? Does someone else give it to them? Do I know that I have... Who makes the game? Do I make the game, or do they make the game?

Sterling here suggests that because his frontstage (neo)liberal presentation of self superficially supports an antiracist and benevolent politics, he should be permitted 
to accommodate any views he wishes in private. Ron Atkinson also offered a similar defence, pointing to his role in promoting and picking Black footballers in the 1980s at West Bromwich Albion, using this as 'proof' that he was not racist (Eboda 2004). What both men wilfully ignore however is that their relationships with Black athletes emerges from a convergence of interest between capital and labour as opposed to any sense of moral obligation and social justice. That is, both Atkinson and Sterling are/or were dependant on Black athletic labour for sporting and economic reasons and both men actively benefit(ed) from such an arrangement. Both then are unwilling to connect their racist ideologies in the backstage with more subtle and covert racism in the frontstage; on the contrary, they see themselves as actively challenging racial arrangements. They operate with what Mills $(1997,17)$ describes as a peculiar moral and empirical epistemology to assist them to make sense of what matters in calculations of morality and the way of the world. Their calculations for cooperation with others in sport include a triad of entrepreneurialism, self-interest and a learned myopic morality.

Once the conversation with Stiviano became public, Sterling, who was evidently still reluctant to accept that his views influence this racialised "culture", took a week to apologise. Furthermore, in an attempt to 'prove' he was not racist, bringing into question what precisely he was apologising for, he set out a series of propositions: Yes, 1) He was baited, 2) He said things that were socially unacceptable, 3) He could see that some would see it as racist, and therefore 4) He has something to apologise for. However, in his eyes he is not racist because a) he 
was 'baited' perhaps meaning that he was led onto the general topic and Stiviano knew his likely questionable response, and b) he was speaking in private, he therefore cannot be held wholly responsible for sentiments that were for her ears only.

Sterling's controversy is further augmented by the curious position of his partner, V. Stiviano, with whom he shared these racist sentiments. In the conversation with Stiviano there was a point when the constructed nature of 'race' and racial identities became the focus of Sterling's racial thesis. In this exchange Stiviano's racial identity, and identification, came into question while her challenge to his racial ideals raised tensions for him. Sterling leads with a comment on his preferred forms of racialised femininities:

Sterling: You're supposed to be a delicate White or a delicate Latina girl... Stiviano: And you're in love with me... And I'm Black and Mexican. Whether you like it or not.

Stiviano's light complexion making her able to pass for White is clearly something that Sterling values, as Blackness for him, though undesirable, in this case is reduced to superficial pigment and physiognomy that can be conveniently ignored. His masculine dominance and manipulation of Stiviano's identity subjugates and oppresses her in a way that has forced Black feminists to 'talk back' (hooks 1989). His willingness to articulate views that reinforce Black oppression at the LA 
Clippers, by marginalizing the African-American presence in elite spaces, demonstrates his confidence that she will accept his tenor and hints at his power over her.

Sullivan and Tuana (2007) perceive such racialised dynamics as an attempt to dominate and oppress: a lived delusional state. A previous outcome of such comments from Sterling before this conversation may have been manifest in Stiviano acquiescing to his bigotry and seemingly endorsing his worldview. Insofar as we often know very little about what goes on in other people's relationships, the dissemination of the private communication (at first by Stiviano to one of her friends and then to TMZ) could be interpreted as Stiviano's retaliation for Sterling's raced and gendered humiliation of her. The cumulative effect of such racial microinsults and microinvalidations, and of living in a racist society that forced her to change her name from Maria Vanessa Perez, given she did not feel fully accepted because of her 'race', seemed to have finally spiked and manifest in her sharing of Sterling's crass diatribe (Sue 2010). hooks $(1989,8)$ would describe Stiviano's actions as,

An act of resistance, a political gesture that challenges politics of domination that would render us nameless and voiceless. As such, it is a courageous act-as such it represents a threat. To those who wield power, that which is threatening must necessarily be wiped out, annihilated, silenced. 
Further to hooks' (1989) foresight of Stiviano's resistance posing a threat to power, on Friday $7^{\text {th }}$ August 2015 Donald Sterling filed a lawsuit against TMZ (the website that published the audio) and Stiviano. For Sterling their actions had caused damage "on a scale of unparalleled and unprecedented magnitude"; they were the ones who were to blame for his lifetime suspension from the NBA and, subsequently, the loss of the LA Clippers to first his wife, Shelly Sterling, and then former Microsoft CEO Steve Ballmer who bought the franchise for a record $\$ 2$ billion.

It could be argued that ego and strategic amnesia conveniently help Sterling to ignore his previous racist behaviours and prosecutions so as to continue his oppression and hostility towards Black and minoritised others. I.e. Sterling ignored his 2006 prosecution by the U.S. Department of Justice for systematic housing discrimination for a refusal to rent to Black people and those with families (ESPN 2006). He was accused of trying to drive out African American and Hispanic residents in select areas of his property empire in a sector repeatedly accused of systematic racism that extends across lenders, insurers, sellers and landlords (Shenglan and Kleiner 2003, Dawkins 2004, Brasington, Hite, and Jauregui 2015). The legacy of these covert practices in housing has led to a segregation of communities, reduced employment and education opportunities based on 'race', while insinuating a pattern of behaviour reflective of Sterling's backstage opinions supporting racial segregation and hierarchies. 
Sterling's refusal to accept that private communications hold relevance outside remote dialogue is a misconstrued belief that must be challenged. Leaving aside for a moment his morally reprehensible views, and a discussion of his right to privacy given this is a different issue - what the Sterling affair illustrates is that he is conscious that where his more dubious opinions are shifted from the backstage to the front they do not always hold the same currency with contrasting audiences because of the higher moral and political expectations in the frontstage. Sterling is another powerful man exposed by opinion and worldview unfiltered by strategic 'political correctness'. Racist words, actions and microaggressions, especially those uttered by Sterling and co. who have the power to influence an entire industry, have real and material effects. For instance, had the audio of Sterling and Stiviano not been made public there is reason to argue of the possibility that Sterling might have pressed for: (1) fewer Black VIPs able to attend LA Clippers games; (2) institutional racial discrimination at different levels of his franchise; (3) the continuation of a "culture" that accepts racialised hierarchies; and (4) a lack of empathy towards "minorities" who work around him and experience racial discrimination in his organisation (see ESPN 2006 for a similar example of Sterling's transgressions).

\section{Conclusion}

Backstage racism is no more significant than frontstage racism yet we know so little about the former and therefore how it might be challenged - not least because of the ethical, legal and constitutional debates and problems empirical investigations into private space incite. Stiviano's bravery to 'out' Sterling is an endeavour fraught with 
ramifications for her, personally and legally, and yet for others privileged to occupy such White spaces it provides an example of how to be more than a bystander and disrupt racist backstage talk. Nonetheless, we suggest that as social scientists when incidents of the backstage become frontstage it offers important insights into Feagin's (2010) White racial frame, insofar as the opinions, attitudes and ideologies that are shared help us to understand that public liberals may exercise a different politics in private (Hughey 2011). In other terms, the type of discussions that are had in private spaces indicate how individuals are likely to lean with regards to 'race', racism, and racialised inequalities in sport and/or how committed they are to social justice agendas. They also provide a chink of light on why life is so much harder for those that Sterling feels are less important than him and other White people.

It can be seen clearly how Donald Sterling's words were intended to reinforce racial hierarchies, divisions and prejudices in the backstage, while in the frontstage, like a sniper's bullet, victims of racism would not know they had been targeted. What we do get to see is a brief sight of the 'script' that sterling works to in the backstage that underpins his more public actions. Where some argue that racism is not conscious and is the domain of untypical, ad hoc behaviour a window on backstage racism suggests otherwise. Implications for racialised and gendered relations in sport emerge strongly here and similar conclusions might be drawn in the cases above of Atkinson, Scudamore, Clarkson, and McKay. 
The cases of Sterling and co. demonstrate how the power to subordinate and oppress can be manifest in private spaces before being wrought in public. Here conscious perpetrators only show remorse when they must answer to others in public spaces. Picca and Feagin (2007), Hughey (2011) and Goffman's (1990 [1959], 14) urgings that authentic dispositions can be best perceived indirectly through individual assertions and what might be viewed as 'involuntary expressive behaviour' illuminate these events and their contexts in sport. In this regard:

Only the sociologist, or the socially disgruntled will have any doubts about the 'realness' of what is presented (Goffman 1990 [1959], 28).

We have also discerned how influential others rapidly defend backstage talk thus making it exigent for meaningful challenges to dominant hegemonies. Sterling's recourse to the law is such a response, partially based upon him not being informed of the recording nor later giving consent to the publication of its contents. He also appeals against a long list of conspirators and leaves the case open to ethical and moral arguments. A consequence of this case is that we demonstrate the potential for research on backstage racism to contribute to explanations of racial inequalities and discrimination in sport. We identify how bystanders to 'race' talk can make a stand against its perpetrators, and that where research can establish such patterns of behaviour in the front and backstage that reinforce these social arrangements we should be able to establish strategies to disrupt them. 
Antiracists often view opportunities to challenge racism as chances to demonstrate success in their struggles, yet commonsense would suggest that in many cases they are reacting to visible sporadic events. It could be argued that by also focusing on long-term backstage racial processes we will better understand the racial disparities in sport. As 'race' and racism are significant structuring factors embedded in the social fabric, narrow and inconsistent approaches to moments of prejudice and bigotry hint at failures to conceive of racism in its more diverse forms behind the frontstage. There is evidently an imperative to explore backstage racism in more detail so that we might intensify our collective understanding of its nature, prevalence, significance and frailties.

\section{References}

Agyemang, K., and J. Singer. 2014. "Race in the Present Day: NBA Employees Sound Off on Race and Racism." Journal of African American Studies 18:11-32.

Back, L , T Crabbe, and J Solomos. 2001. The Changing Face of Football: Racism, Identity and Multiculture in the English Game. Oxford: City.

Back, L, T Crabbe, and J Solomos. 1999. "Beyond the racist/hooligan couplet: 'race,' social theory and football culture." British Journal of Sociology 50 (3):419442.

BBC. 2014. "Malky Mackay: Ex-Cardiff boss sorry for two 'disrespectful' texts." Accessed 1st November 2014. http://www.bbc.co.uk/sport/0/football/28890833.

Bonilla-Silva, E. 2010. Racism without racists: Color-blind racism and the persistence of racial inequality in the United States Lanham, Maryland: Rowman \& Littlefield Pub Inc.

Bradbury, S., J. van Sterkenburg, and P. Mignon. 2015. The glass ceiling in European football: Levels of representation of visible ethnic minorities and women in leadership positions, and the experiences of elite level ethnic minority coaches. http://WWW.Farenet.org: FARE.

Brasington, D., D. Hite, and A. Jauregui. 2015. "House Price Impacts of Racial, Income, Education, and Age Neighbourhood Segregation." Journal of Regional Science 55 (3):442-467. 
Burdsey, D. 2004. "Obstacle race? 'race', racism and the recruitment of British Asian professional footballers." Patterns of Prejudice 38 (3):279-299. doi: 10.1080/0031322042000250466.

Burdsey, D. 2011. "That Joke Isn't Funny Anymore: Racial Microaggressions, ColourBlind Ideology an the Mitigation of Racism in English Men's First Class Cricket." Sociology of Sport Journal 28:261-283.

Carrington, B. 2013. "The Critical Sociology of Race and Sport: The First 50 Years." Annual Review of Sociology 39:379-398. doi: 10.1146/annurev-soc-071811145528.

Cashmore, E., and J. Cleland. 2011. "Why aren't there more Black football managers?" Ethnic and Racial Studies 34 (9):1594-1607. doi: 10.1080/01419870.2011.595556.

Cleland, J., and E. Cashmore. 2014. "Fans, Racism and British Football in the TwentyFirst Century: The Existence of a 'Colour-Blind' Ideology." Journal of Ethnic \& Migration Studies 40 (4):638-654. doi: 10.1080/1369183X.2013.777524.

Dawkins, J. 2004. "Recent Evidence on the Continuing Causes of Black-White Residential Segregation." Journal of Urban Affairs 26 (3):379-400.

Delgado, R., and J. Stenfancic. 2012. Critical Race Theory: An Introduction. Vol. null, null.

Duru, J. N. 2011. Advancing the Ball: Race, Reformation and the quest for equal opportunity in the NFL. New York: OUP.

Eboda, M. 2004. "'What I said was racist - but I'm not a racist. I am an idiot'." The Guardian, Sunday 25 April 2004. http://www.theguardian.com/uk/2004/apr/25/race.football.

ESPN. 2006. "Sterling sued by DOJ for housing discrimination." Accessed 20th September 2015. http://sports.espn.go.com/nba/news/story?id=2542741.

Feagin, J. 2010. The white racial frame : Centuries of racial framing and counterframing. London: Routledge.

Fine, M. 2004. "Witnessing Whiteness/Gathering Intelligence." In Off White: Readings on power, privilege, and resistance, edited by M. Fine, L. Weis, L. Powell and A. Burns, 245-256. New York and London: Routledge.

Fleming, S., A. Hardman, C. Jones, and H. Sheridan. 2005. "'Role models' among elite young male rugby league players in Britain." European Physical Education Review 11 (1):51-70. doi: 10.1177/1356336x05049824.

Goffman, E. 1990 [1959]. The Presentation of self in everyday life. London: Penguin Books.

Home Office. 2014. Football-related arrests and football banning order statistics: Season 2013-14. London: Home Office.

hooks, b. 1989. Talking Back: thinking feminist, thinkig black. Boston: South End Press.

Hughey, M. 2011. "Backstage Discourse and the Reproduction of White Masculinities." Sociological Quarterly 52 (1):132-153.

Hughey, M. W, and D. R Goss. 2015. "A Level Playing Field? Media Constructions of Athletics, Genetics, and Race." The ANNALS of the American Academy of Political and Social Science 661 (1):182-211. 
Hylton, K. 2015. "'Race' Talk! Tensions and Contradictions in Sport and PE." Physical Education and Sport Pedagogy. doi: 10.1080/17408989.2015.1043253.

Hylton, K., and S. Lawrence. 2014. "Reading Ronaldo: contingent whiteness in the football media." Soccer and Society iFirst. doi: http://dx.doi.org/10.1080/14660970.2014.963310.

Jensen, R. 2005. The heart of whiteness : confronting race, racism, and white privilege. San Francisco, CA: City Lights.

Johnson, D. 2013. "Tottenham Hotspur and West Ham United supporters could be arrested for chanting 'Yid', Met warns." The Daily Telegraph, 3/10/13.

Accessed 6/10/14.

http://www.telegraph.co.uk/sport/football/teams/tottenhamhotspur/10353969/Tottenham-Hotspur-and-West-Ham-United-supporterscould-be-arrested-for-chanting-Yid-Met-warns.html.

Lawrence, S. 2014a. "'Becoming white' and (un)learning colour-blindness: Stefan's story." Leisure Studies Association 2014: Sport, Festivity and Digital Cultures, Paisely, University of the West of Scotland, July 7th-9th.

Lawrence, S. 2014b. "Racialising the "great man": A Critical Race study of idealised male athletic bodies in Men's Health magazine." International Review for the Sociology of Sport. doi: 10.1177/1012690214555347.

Leonard, D. 2004. "The next M. J. or the next O. J.? Kobe Bryant, race and the absurdity of colorblind rhetoric." Journal of Sport \& Social Issues 28 (3):284313.

Leonardo, Z. 2009. Race, whiteness, and education. New York; London: Routledge.

Long, J., and K. Spracklen, eds. 2011. Sport and Challenges to Racism. London: Routledge.

Lorenz, S., and R. Murray. 2014. "“Goodbye to the Gangstas": The NBA Dress Code, Ray Emery, and the Policing of Blackness in Basketball and Hockey." Journal of Sport and Social Issues 38 (1):23-50.

Love, A., and M. Hughey. 2015. "Out of bounds? Racial discourse on college basketball message boards." Ethnic and Racial Studies 8 (6):877-893.

Lucas, D. 2014. "Premier League's Richard Scudamore apologises for 'inappropriate' emails." The Guardian, Sunday 11th May. Accessed 19th May 2015. http://www.theguardian.com/football/2014/may/11/richard-scudamoreapologises-inappropriate-emails-accused-sexism.

Maguire, J. 1991. "Sport, racism and British society: A sociological study of England's elite male Afro-Caribbean soccer and rugby union players." In Sport, racism and ethnicity, edited by G. Jarvie, 94-123. London: Falmer.

Mason, P. 2013. Encyclopedia of 'Race' and Racism Detroit: MacMillan Reference.

Mills, C. 1997. The Racial Contract. Ithaca: Cornell University.

Muller, F., L. van Zoonen, and L. de Roode. 2007. "Accidental Racists: Expereinces and Contradictions of Racism in local Amsterdam Soceer Fan Culture." Soccer and Society 8 (2/3).

Picca, Leslie Houts, and Joe R. Feagin. 2007. Two-faced racism : Whites in the backstage and frontstage. New York ; London: Routledge.

Poulton, E., and O. Durell. 2014. "Uses and meanings of 'Yid' in English football fandom: A case study of Tottenham Hotspur Football Club." International 
Review for the Sociology of Sport:1-20. doi: DOI:

$10.1177 / 1012690214554844$.

Puwar, N. 2004. Race, Gender and Bodies Out of Place. Oxford: Berg.

Rains, F. 2000. "Is the benign really harmless?" In White Reign: Deploying whiteness in America, edited by J. Kincheloe, S. Steinberg, N. Rodriguez and R. Chennault, 77-101. New York: St. Martin's Griffin.

Ratna, A. 2011. "'Who wants to make aloo gobi when you can bend it like Beckham?' British Asian females and their racialised experiences of gender and identity in women's football." Soccer \& Society 12 (3):382-401. doi: $10.1080 / 14660970.2011 .568105$.

Ratna, A., S. Lawrence, and J. Partington. 2015. "'Getting inside the wicket': strategies for the social inclusion of British Pakistani Muslim cricketers." Journal of Policy Research in Tourism, Leisure and Events:1-17. doi: 10.1080/19407963.2015.1065267.

RunnymedeTrust. 1985. "National Front and Football Violence." Runnymede Trust Bulletin, May.

Shenglan, C., and B. Kleiner. 2003. "Housing Discrimination Based on Race." Equal Opportunities International 22 (3):16-48.

Solomos, J., and L. Back. 1996. Racism and Society Basingstoke: Palgrave MacMillan.

Sue, D. 2010. "An Introduction." In Microaggressions, Marginality, and Oppression, edited by D. Sue. New Jersey: John Wiley and Sons, Inc.

Sullivan, S., and N. Tuana, eds. 2007. Race and epistemologies of Ignorance. Albany: State University of New York Press.

TelegraphSport. 2013. "Andre Villas-Boas welcomes David Cameron's support for Tottenham fans' 'Yid' chants." The Daily Telegraph, 19th September, 2013. Accessed 6/10/14. http://www.telegraph.co.uk/sport/football/teams/tottenhamhotspur/10319722/Andre-Villas-Boas-welcomes-David-Camerons-supportfor-Tottenham-fans-Yid-chants.html.

TMZ. 2014. In Clippers Owner Donald Sterling to Girlfriend: Don't Bring Black People to My Games (Audio).

van Sterkenburg, J., A. Knoppers, and S. Leeuw. 2010. "Race, ethnicity, and content analysis of the sports media: a critical reflection." Media, Culture \& Society 32 (4):819-839. 